\title{
Partial characterization of a major autolysin from Mycobacterium phlei
}

\author{
Zusheng S. Li, ${ }^{1}+$ Terry J. Beveridge, ${ }^{1}$ Joanna Betts ${ }^{2}$ \\ and Anthony J. Clarke ${ }^{1}$
}

\begin{abstract}
Author for correspondence: Anthony J. Clarke. Tel: +1 5198244120 ext. 3361. Fax: +1 5198371802. e-mail : aclarke@micro.uoguelph.ca
\end{abstract}

\author{
1 Canadian Bacterial \\ Diseases Network, \\ Department of \\ Microbiology, University of \\ Guelph, Guelph, Ontario \\ N1G 2W1, Canada \\ 2 Immunopathology Unit, \\ Glaxo Wellcome Research \\ and Development, Gunnels \\ Wood Road, Stevenage \\ SG1 2NY, UK
}

\begin{abstract}
Autolytic enzyme profiles of fast- and slow-growing mycobacteria were examined using SDS-PAGE zymography with incorporated mycobacterial peptidoglycan sacculi as substrate. Each species tested (Mycobacterium phlei, Mycobacterium smegmatis, Mycobacterium aurum, Mycobacterium fortuitum and Mycobacterium kansasii) appeared to produce a different set of enzymes on the basis of differing number and molecular masses. A major autolysin from $M$. phlei was purified to apparent homogeneity by DEAE-cellulose chromatography, preparative gel electrophoresis and Mono Q FPLC. This enzyme had an estimated molecular mass of $38 \mathrm{kDa}$, an isoelectric point of 5.5 and a pH optimum of pH 7.5. Digestion of purified peptidoglycan by the enzyme resulted in the appearance of reducing sugars, suggesting that the $38 \mathrm{kDa}$ autolysin is a $\beta$-glycosidase. Partial internal amino acid sequence of the autolysin was determined and should facilitate identification, cloning and overexpression of the encoding gene.
\end{abstract}

Keywords: Mycobacterium phlei, autolysin, $\beta$-glycosidase

\section{INTRODUCTION}

Mycobacteria have a unique cell-wall structure that is characterized by a large number of lipids with unusual structures, such as mycolic acids with associated shortchain fatty acids and peptides. These wall components are anchored through arabinogalactan to the peptidoglycan layer. For pathogenic species, the cell wall is believed to: be partly responsible for the ability to colonize host cells; stimulate a myriad of immune responses; evade attack by host immune strategies; and promote chronic debilitating diseases (Barclay \& Wheeler, 1989). Diverse immune reactions have been attributed to several components of the wall including proteins (Hunter et al., 1989), muramyl dipeptide (Puzo, 1990), sulfolipids (Barclay \& Wheeler, 1989; Puzo, 1990), glycolipids, lipooligosaccharides and lipoarabinomannan (Ellner \& Daniel, 1979; Moreno et al., 1988). As the backbone of the cell wall, to which all other substances are bound, the peptidoglycan is of

\footnotetext{
†Present address: Department of Microbiology and Immunology, Temple University School of Medicine, 3400 North Broad Street, Philadelphia, PA 19140, USA.

The SWISS-PROT accession number for the Mycobacterium phlei autolysin reported in this paper is $\mathbf{P 8 1 5 2 8 .}$
}

utmost importance. Little is known about cell-wall turnover in mycobacteria, which is a pre-requisite for bacterial growth and division; such turnover must ultimately be controlled by peptidoglycan metabolism (Höltje, 1996; Koch, 1990; Rogers et al., 1980; Shockman et al., 1996; Tomasz, 1984).

During growth and division, modification of the bacterial cell wall requires coordinated functions of peptidoglycan hydrolases and peptidoglycan synthases, including the penicillin-binding proteins (PBPs). The PBPs and peptidoglycan hydrolases were recently proposed to form a multi-enzyme complex in Escherichia coli to expand the existent structure of its murein sacculus (Höltje, 1996, 1998). Lytic peptidoglycan hydrolases can be described as autolysins since their uncontrolled action can result in the breakdown of the structural integrity and protective properties of the wall. These autolysins, like all enzymes, have discrete specificity and comprise three major classes: $\beta$-glycosidases $(\beta$-N-acetylmuramidase and $\beta$-N-acetylglucosaminidase), $N$-acetylmuramoyl-L-alanine amidase and D,D-endopeptidases, which hydrolyse peptide cross-bridges (reviewed by Shockman \& Höltje, 1994; Höltje, 1998). In view of their potentially lethal action, the tightly controlled function of the autolysins seems to be an essential role in the metabolism of the murein sacculus (Koch, 1990; 
Rogers et al., 1980; Shockman et al., 1996; Tomasz, 1984).

Our long-term goal is to understand how autolysins are involved in cell-wall turnover in mycobacteria, and how the turnover products (which are most likely a cascade of immunodominant substances) interact with hosts to induce, for example, immunogenic and pathogenic responses. Although autolysis in mycobacteria was observed over two decades ago (Kilburn \& Best, 1977), to date, the individual autolysins have not been isolated and studied. This is probably due to the low expression level of autolysins and consequent difficulties in detection, especially in slow-growing bacteria. Moreover, the difficulties associated with the in vitro growth of mycobacterial cultures has further hindered progress.

The recent development of a zymogram-based method for the detection of autolysins from Gram-negative bacteria (Bernadsky et al., 1994; Watt \& Clarke, 1994) has provided a sensitive means to study the mycobacterial enzymes; here, we identify for the first time autolysins from both fast- and slow-growing mycobacterial species, and partially characterize a major autolysin from Mycobacterium phlei.

\section{METHODS}

Bacteria and growth conditions. M. phlei, M. smegmatis, $M$. aurum, M. fortuitum and $M$. kansasii used in the present study were from our own collection (Paul \& Beveridge, 1992, 1994). M. kansasii was grown in 7 H9 broth (Difco) supplemented (per litre) with 6 egg yolks, $100 \mathrm{ml}$ oleic acid/ albumin/dextrose/catalase (OADC; Difco), 100000 units penicillin $\mathrm{G}$ and $0.05 \mathrm{~g}$ chloramphenicol (antibiotics are routinely added to prevent the growth of any contaminants during the slow growth of mycobacteria). All other mycobacterial species were grown in brain-heart infusion broth (BBL, Becton Dickinson), supplemented with $0.5 \%(\mathrm{v} / \mathrm{v})$ glycerol and $0.05 \%(\mathrm{v} / \mathrm{v})$ Tween 80 . Routinely, bacteria were grown to $\mathrm{OD}_{600} 0 \cdot 8-1 \cdot 0$ (late-exponential phase) at $37^{\circ} \mathrm{C}$ with occasional shaking.

Preparation of peptidoglycan. Peptidoglycan sacculi were isolated from the various species of mycobacteria by the method of Hoyle \& Beveridge (1984).

Zymogram analysis. Zymogram analysis of peptidoglycan hydrolases was performed as previously described (Bernadsky et al., 1994; Li et al., 1996; Watt \& Clarke, 1994) with isolated peptidoglycan sacculi $(1 \%, w / v)$ from $M$. fortuitum, $M$. kansasii, M. phlei or M. smegmatis as substrate in the gels. In some cases, the period of destaining was shortened to facilitate the visualization of minor bands, resulting in different background intensities between gels. For presentation, gels were digitized using a Gel Doc 1000 UV fluorescent gel documentation system (Bio-Rad) as previously described (Watt \& Clarke, 1994).

To test the influence of protease inhibitors on the activity of autolysins during zymogram analysis, a cocktail of 10 protease inhibitors (Complete; Boehringer Mannheim) was added to samples prior to electrophoresis. BSA was used as a positivecontrol substrate.

Purification of the major M. phlei autolysin. All steps during purification were carried out at $4{ }^{\circ} \mathrm{C}$ or on ice unless otherwise noted.

Crude cellular extract. Freeze-dried cells (1.5 g) were washed once in Milli-Q water and resuspended in $160 \mathrm{ml} 20 \mathrm{mM}$ sodium phosphate buffer, $\mathrm{pH} 8.0$ (extraction buffer). The bacterial suspension was sonicated (Braun, Sonic 2000) for $20 \mathrm{~min}$ at $150 \mathrm{~W}$. Most (99\%) of the cells were broken after sonication, as visualized by microscopy. To this cell extract, DNase and RNase were added to a final concentration of $50 \mu \mathrm{g} \mathrm{ml}^{-1}$ each. The extract was kept on ice for $1 \mathrm{~h}$ and then subjected to centrifugation at $9000 \mathrm{~g}$ for $10 \mathrm{~min}$ to separate supernatant (crude cellular extract) from the remaining particulate matter.

DEAE-cellulose chromatography. The extraction buffer was used to pack and equilibrate a $50 \times 2.2 \mathrm{~cm}$ column of DEAEcellulose (Sigma). The clarified cell extract was applied at a flow rate of $1 \mathrm{ml} \mathrm{min}^{-1}$ and non-adsorbing materials were washed from the column using the extraction buffer. The autolysin was eluted by applying a linear $\mathrm{NaCl}$ gradient $(0-0.75 \mathrm{M})$ in $20 \mathrm{mM}$ sodium phosphate buffer, $\mathrm{pH} 6.5$, and $5 \mathrm{ml}$ fractions were collected. The protein concentration in each fraction was monitored by measuring its absorbance at $280 \mathrm{~nm}$ and the $\mathrm{NaCl}$ concentration in each fraction was determined as described below. For quick detection of fractions containing active enzyme, $100 \mu \mathrm{l}$ from each of 10 fractions were combined and freeze-dried for zymogram analysis. Positive combined fractions were analysed further by zymography to precisely locate the enzyme-containing fractions. Individual fractions containing autolytic activity were pooled, freeze-dried, resuspended in a small amount of deionized water and dialysed against 61 deionized water for $2 \mathrm{~d}$ with at least two changes of water during this period.

Preparative gel electrophoresis. This was performed in a $12 \%$ polyacrylamide separating gel under non-denaturing (native) conditions using a model 491 Prep Cell (Bio-Rad). The flow rate of the buffer through the elution chamber was set to $1 \mathrm{ml}$ $\min ^{-1}$. Fractions of $2.5 \mathrm{ml}$ per tube were collected after the tracking dye had migrated to the elution chamber. The protein concentration in each fraction was monitored by measuring its absorbance at $280 \mathrm{~nm}$ while enzymic activity was assessed by the zymogram method described above. Active fractions were pooled, freeze-dried and dialysed against $20 \mathrm{mM}$ sodium phosphate buffer, $\mathrm{pH} 8 \cdot 0$.

Mono Q anion-exchange FPLC. A Mono Q HR 5/5 anionexchange column was equilibrated with $10 \mathrm{mM} \mathrm{NaCl}$ in $20 \mathrm{mM}$ sodium phosphate buffer, $\mathrm{pH} 8.0$, for at least $2 \mathrm{~h}$ at room temperature. Fractions from the preparative gel electrophoresis (above) were applied to the column after the flow rate was set to $1.0 \mathrm{ml} \mathrm{min}-1$. The column was first eluted with the same buffer as above for $10 \mathrm{~min}$ and then a linear $\mathrm{NaCl}$ gradient $(0.01-1.0 \mathrm{M}$ over $70 \mathrm{~min})$ in the same phosphate buffer was applied. Fractions of each peak were collected, freeze-dried and analysed for activity by zymography. The purity of the active fraction was analysed by SDS-PAGE and 2D gel electrophoresis.

Turbidometric assay of enzymic activity. Autolytic activity of various samples was quantitatively measured by the turbidometric assay as described by Dolinger et al. (1989). A standard assay consisted of a sample of autolysin added to $0.5 \mathrm{mg}$ (wet wt) $M$. smegmatis cell walls in $20 \mathrm{mM}$ Tris/ $\mathrm{HCl}$ buffer, $\mathrm{pH}$ $7 \cdot 0$, containing $10 \mathrm{mM} \mathrm{MgCl}_{2}, 0 \cdot 1 \%$ (w/v) Triton X-100 and $0.05 \%(\mathrm{w} / \mathrm{v}) \mathrm{NaN}_{3}$ in a final volume of $1.0 \mathrm{ml}$. Digestion of cell-wall fragments was monitored by measuring the decrease in $\mathrm{OD}_{540}$ of the suspension over time. One enzymic unit was 
defined as the amount of activity causing a decrease in $\mathrm{OD}_{540}$ of 0.001 after $24 \mathrm{~h}$ incubation at $37^{\circ} \mathrm{C}$.

Determination of molecular mass. A Superdex 75 HR 10/30 gel filtration column was equilibrated with $20 \mathrm{mM}$ sodium phosphate buffer, $\mathrm{pH} 7 \cdot 0$, for $2 \mathrm{~h}$ at room temperature. The autolysin sample was applied to the column at a flow rate of $0 \cdot 3 \mathrm{ml} \mathrm{min}^{-1}$. The column was eluted with the same buffer and the elution volume of the autolysin was recorded. In parallel experiments, blue dextran and protein molecular mass standards (Sigma) were applied to the column to obtain a calibration curve.

$\mathrm{pH}$ optimum of the autolysin. The $\mathrm{pH}$ optimum of the major autolysin was determined by using the recently developed spot assay (Watt \& Clarke, 1997) with modifications. Briefly, molten $4 \%$ Noble agar, held at $60^{\circ} \mathrm{C}$, was mixed with peptidoglycan sacculi suspended in buffers of various $\mathrm{pHs}$ to give plates containing $0 \cdot 1 \%$ (wet wt $; \mathrm{w} / \mathrm{v}$ ) peptidoglycan. The buffers were: $20 \mathrm{mM}$ sodium citrate/phosphate, $\mathrm{pH} 4 \cdot 0-\mathrm{pH}$ $7 \cdot 0 ; 20 \mathrm{mM}$ sodium phosphate, $\mathrm{pH} 6 \cdot 0-8 \cdot 0 ; 20 \mathrm{mM}$ Tris $/ \mathrm{HCl}$, $\mathrm{pH} 7 \cdot 0-9 \cdot 0 . \mathrm{MgCl}_{2}$, Triton $\mathrm{X}-100$ and $\mathrm{NaN}_{3}$ were added to all buffers as above. Samples $(5 \mu \mathrm{l})$ of the enzyme fractions were spotted as single drops onto plates and the diameter of clear zones was quantitatively measured after incubation of the plate for $24 \mathrm{~h}$ at $37^{\circ} \mathrm{C}$.

Isoelectric point determination. Isoelectric focusing was done in a vertical polyacrylamide mini-gel system (Bio-Rad) according to the method of Robertson et al. (1987). The $\mathrm{pH}$ gradient of the gels was determined by measuring the $\mathrm{pH}$ of each slice cut from one side of the gel after it had been soaked in deionized water, or by comparing the enzyme with protein standards of known pI (IEF standards in the range of 4.8-10.6; Pharmacia).

Amino acid composition analysis. Protein bands were electroblotted from an SDS-PAGE gel onto an Immobilon-P transfer membrane (Millipore) and amino acid composition analysis was performed as previously described (Li et al., 1993).

Internal amino acid sequencing. The protein of interest was excised from a Coomassie blue-stained polyacrylamide gel and digested in situ with trypsin. Amino acid sequencing of digested peptides by nano-electrospray mass spectrometry was performed as previously described (Wilm et al., 1996).

Specificity of the autolysin. After digestion of peptidoglycan samples by the autolysin at $37^{\circ} \mathrm{C}$ for $24 \mathrm{~h}$ in the renaturing buffer, reducing sugar content was measured colorimetrically by the method of Lever (1972), while the appearance of free amino groups was assayed by the method of Ghuysen $e t$ al. (1966).

Analytical techniques. The $\mathrm{NaCl}$ concentrations in the eluate from DEAE-cellulose chromatography were determined by measuring the conductivity of a sample with a series of solutions of known $\mathrm{NaCl}$ concentrations as standards. Protein concentrations were estimated by either UV-absorbance spectroscopy at $280 \mathrm{~nm}$ or the Bio-Rad Protein Assay Kit with BSA as the standard.

\section{RESULTS AND DISCUSSION}

\section{Autolytic enzyme profiles}

The autolytic enzyme profiles of fast- and slow-growing mycobacteria were examined by zymogram analysis with peptidoglycan purified from the various myco-

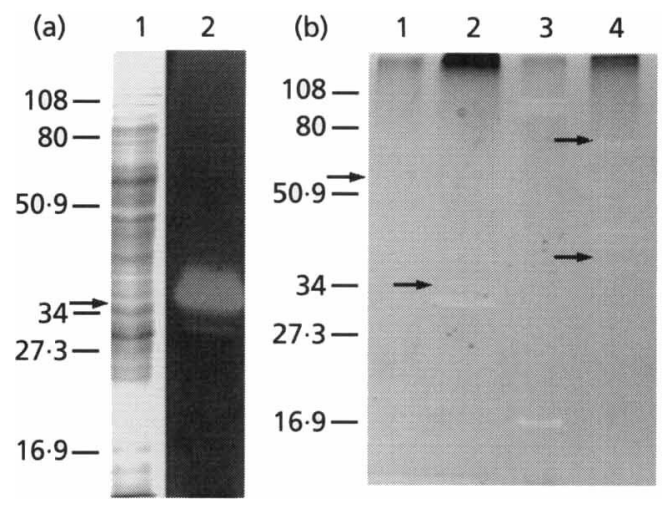

Fig. 1. Autolysin profiles of mycobacteria by zymography using $12.5 \%$ polyacrylamide gels containing $1 \%$ (wet wt) peptidoglycan sacculi from $M$. smegmatis as substrate. (a) Analysis of extracts from $M$. phlei. Lane 1, SDS-PAGE with Coomassie blue staining of crude cellular extract; lane 2, zymogram analysis of crude cellular extract. (b) Zymogram profiles of crude extracts from $M$. kansasii (lane 1), $M$. smegmatis (lane 2), $M$. aurum (lane 3 ) and $M$. fortuitum (lane 4). Arrows denote the poorly detected bands. Positions of prestained low-molecular-mass markers (in $\mathrm{kDa}$ ) are indicated on the left of each panel.

bacterial species as substrate. The typical lytic profile of autolysins from $M$. phlei in a zymogram gel with peptidoglycan sacculi from M. smegmatis as substrate is shown in Fig. 1 (a), lane 2, and those of M. kansasii, $M$. smegmatis, $M$. aurum and $M$. fortuitum are shown in Fig. 1 (b). The approximate molecular masses of the autolysins in these mycobacteria are: $M$. phlei, $38 \mathrm{kDa}$ (major) and $33 \mathrm{kDa}$ (Fig. 1a, lane 2); M. kansasii, $64 \mathrm{kDa}$ (major) and $61 \mathrm{kDa}$ (minor, arrowhead, only clearly seen on the zymogram gel) (Fig. 1b, lane 1); $M$. smegmatis, $34 \mathrm{kDa}$ (minor, arrowed) and $31 \mathrm{kDa}$ (major) (Fig. 1b, lane 2); M. aurum, $16 \mathrm{kDa}$ (major), $95 \mathrm{kDa}$ and $104 \mathrm{kDa}$ (minor) (Fig. 1b, lane 3); $\mathrm{M}$. fortuitum, 38 (arrowed), 42, 45, 73 (arrowed) and $76 \mathrm{kDa}$ (Fig. 1b, lane 4). Virtually identical enzyme profiles of these mycobacteria were observed when peptidoglycan sacculi from either M. phlei, $M$. fortuitum, or M. kansasii were used as substrates in the zymogram analysis. Of the autolysins observed in the zymograms, the $38 \mathrm{kDa}$ enzyme of $M$. phlei appeared to have the highest activity based on the size of the clearing zone and, because of this, it was the one that we chose to purify and characterize. Despite its apparent strong activity in the zymogram gel, staining with either Coomassie blue (Fig. 1a, lane 1; arrowed) or silver nitrate suggested that the $38 \mathrm{kDa}$ autolysin was a minor cellular protein.

Autolytic activity has previously been detected in $M$. smegmatis by chemical analysis of autolytic digests of isolated cell walls (Kilburn \& Best, 1977). The detected activities included $N$-glycoylmuramoyl-L-alanine amidase, aminopeptidase and endopeptidase activities. However, no particular protein(s) associated with these enzyme activities was thereafter identified or purified. 
Table 1. Purification of the $38 \mathrm{kDa}$ autolysin from M. phlei from 1 I of cell culture grown to late exponential phase

\begin{tabular}{|lcccccc|}
\hline Purification step & $\begin{array}{c}\text { Total } \\
\text { vol. } \\
(\mathbf{m l})\end{array}$ & $\begin{array}{c}\text { Total } \\
\text { protein } \\
(\mathbf{m g})\end{array}$ & $\begin{array}{c}\text { Total } \\
\text { activity } \\
(\mathbf{U})\end{array}$ & $\begin{array}{c}\text { Specific } \\
\text { activity } \\
\left(\mathbf{U ~ m g}^{-1}\right)\end{array}$ & $\begin{array}{c}\text { Recovery } \\
(\%)\end{array}$ & $\begin{array}{c}\text { Purification } \\
\text { factor }\end{array}$ \\
\hline Crude cell extract & 160 & 1230 & 7800 & $6 \cdot 4$ & 100 & 1 \\
DEAE-cellulose & 20 & 40 & 3300 & 82 & 42 & 13 \\
Preparative gel electrophoresis & 5 & 3 & 875 & 292 & 11 & 46 \\
Mono Q anion exchange FPLC & 2 & $0 \cdot 32$ & 408 & 1275 & $5 \cdot 2$ & 199 \\
\hline
\end{tabular}

To our knowledge, no other investigations have been reported on mycobacterial autolysins. Our results indicated that all tested strains of mycobacteria possess two or more autolytic enzymes.

The observation that autolysins in one species of mycobacteria could act on peptidoglycan of different species suggests common structural features among the cell walls of these species. These mycobacteria are generally thought to possess A1 $\gamma$ peptidoglycan containing the characteristic D-alanyl-meso-diaminopimelic acid interpeptide linkage (Schleifer \& Kandler, 1972), but an unusual meso-diaminopimelyl-meso-diaminopimelic acid cross-linkage has also been detected in both M. smegmatis and M. tuberculosis (Wietzerbin et al., 1974). There have been no reports suggesting that the glycan moiety is O-acetylated (Clarke \& Dupont, 1992). Thus, the overall structure of peptidoglycan in mycobacteria, even though complexed with a variety of additional unusual secondary constituents, seems comparable to that of several Gram-positive (e.g. Bacillus subtilis) and most Gram-negative bacteria. These bacteria also have $\mathrm{A} 1 \gamma$ peptidoglycan and they express their individual complement of autolysins (Bernadsky et al., 1994; Foster, 1992; Goodell \& Schwartz, 1977; Höltje, 1996; Schwartz et al., 1969; Watt \& Clarke, 1994). Clearly, mycobacterial autolysins from one species are capable of degrading the cell walls from other mycobacteria and it is not unusual for an autolysin to have rather broad activity. For example, those isolated from Pseudomonas aeruginosa have been shown to hydrolyse the A1 $\gamma$ peptidoglycan from different genera and species of Gram-negative bacteria (Watt \& Clarke, 1997). However, the presence of either $\mathrm{O}$-acetyl substituents on the peptidoglycan of Proteus mirabilis or teichoic acids in Gram-positive bacteria prevented hydrolysis by the $P$. aeruginosa $26 \mathrm{kDa}$ autolysin, suggesting that this and other enzymes from different Gram-negative bacteria may not act on highly substituted A $1 \gamma$ peptidoglycan such as that produced by the mycobacteria.

\section{Purification of the $M$. phlei $38 \mathrm{kDa}$ enzyme}

Purification of the $38 \mathrm{kDa}$ autolysin to apparent homogeneity was achieved by a four-step procedure summarized in Table 1 and Fig. 2. Most of the enzyme

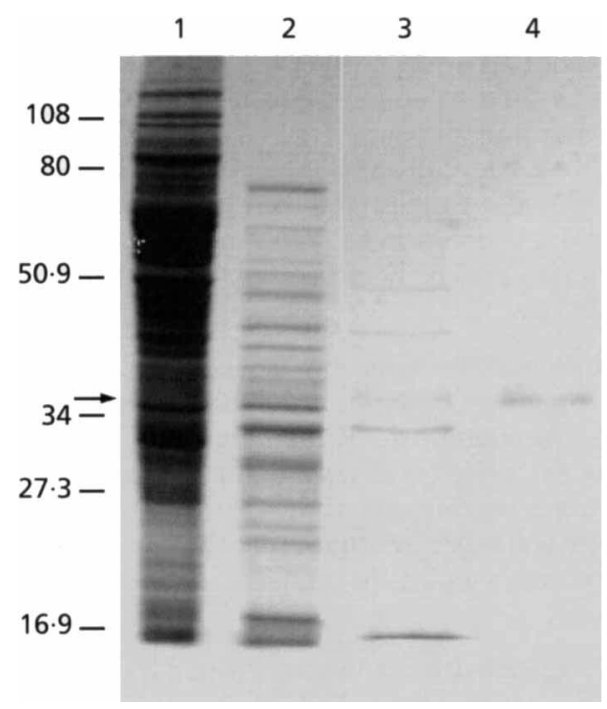

Fig. 2. SDS-PAGE analysis of samples obtained at various steps of purification of $M$. phlei $38 \mathrm{kDa}$ autolysin. Lane 1, crude cellular extract; lane 2, DEAE-cellulose eluate containing autolysin; lane 3, preparative gel electrophoresis eluate containing autolysin; lane 4, fraction 10 from the Mono Q column. Material loaded into lanes 1, 2 and 3 is from the same number of cells, but 5-fold more material was loaded into lane 4. The arrow shows the position of the $38 \mathrm{kDa}$ autolysin. Positions of prestained low-molecular-mass markers (in $\mathrm{kDa}$ ) are indicated on the left

activity present in the cells was liberated by ultrasonication in dilute buffer (Fig. 1a, lane 2) suggesting a surface (i.e. cell wall) location for the enzyme; only trace activity was detected in the remaining cell debris. An extraction of the cell sonicate with $5 \mathrm{M} \mathrm{LiCl}$ recovered a similar amount of autolytic activity but given the added need of a dialysis step to remove the salt, this extraction protocol was not used for routine purifications. After binding the autolysin to DEAE-cellulose, lipids and unadsorbed proteins in the supernatant were readily removed. Among many proteins bound to the DEAEcellulose only a small proportion (fractions 24-59), including the $38 \mathrm{kDa}$ autolysin, eluted with $0 \cdot 03-0 \cdot 1 \mathrm{M}$ $\mathrm{NaCl}$ (see Fig. 3b for zymographic analysis of fractions 11-70). The majority of other bound proteins were 


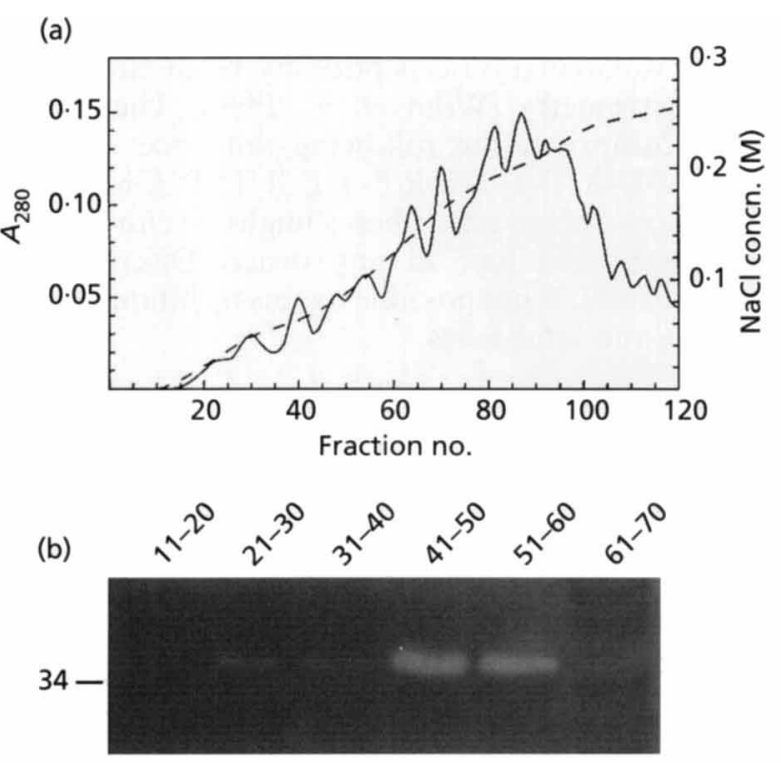

Fig. 3. Chromatography of $M$. phlei extract on DEAE-cellulose. (a) Elution profile of proteins as detected by absorbance at $280 \mathrm{~nm}$ (solid line) using a linear $\mathrm{NaCl}$ gradient (dotted line) in $20 \mathrm{mM}$ sodium phostphate buffer, pH 6.5. (b) Zymogram analysis of fractions $11-70$ of eluate ( $20 \mu \mathrm{g}$ total protein of each fraction). The four combined fractions from 21 to 60 contained the enzyme activity. Position of a prestained low-molecularmass marker (in $\mathrm{kDa}$ ) is indicated on the left.

eluted with $\mathrm{NaCl}$ concentrations higher than $0 \cdot 1 \mathrm{M}$ (Fig. $3 a)$.

Native preparative gel electrophoresis was then applied to the partially purified autolysin. Although many contaminating proteins were removed, resulting in a 46fold purification of the enzyme, considerable enzyme activity was lost during this step (Table 1 ). The protein concentration in each fraction was too low to be monitored, but active fractions were easily detected by zymogram analysis. Eventual purification of the enzyme was achieved by Mono Q anion-exchange chromatography of these active fractions from preparative gel electrophoresis. A typical protein elution profile is shown in Fig. 4(a). The enzyme eluted as a single peak in $0.23 \mathrm{M} \mathrm{NaCl}$ (Fig. 4a, fraction 10) and its autolytic activity was clearly seen after zymogram analysis (Fig. $4 b)$.

To our knowledge, this represents the first report of the isolation and purification of a mycobacterial autolysin. Although we were successful in obtaining the purified protein, the purification protocol has limited applications because of the apparent minor quantity of total autolysin expressed in the cells and the difficulty of its recovery (Fig. 1a, lane 1; Table 1). For this reason, in future experiments we will attempt to isolate the encoding gene and overexpress it in a suitable host system.
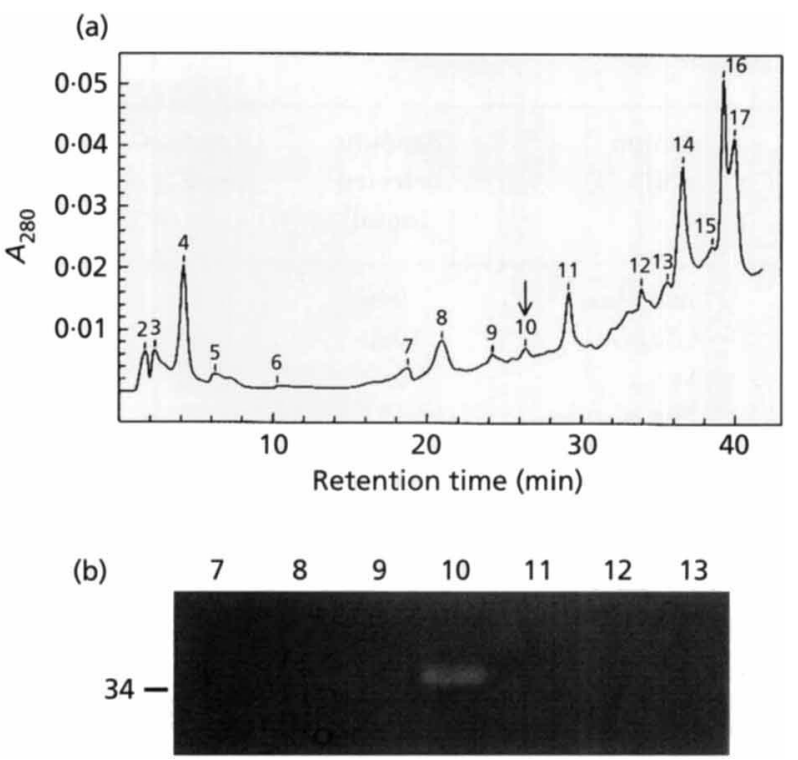

Fig. 4. Purification of the $38 \mathrm{kDa}$ autolysin by Mono $\mathrm{Q}$ anionexchange chromatography. (a) The enzyme was applied to the column in $20 \mathrm{mM}$ sodium phosphate buffer, $\mathrm{pH} 8$, at $1.0 \mathrm{ml}$ $\mathrm{min}^{-1}$ and eluted with a linear $\mathrm{NaCl}$ gradient $(0.01-1.0 \mathrm{M})$ over $70 \mathrm{~min}$. The arrow indicates the fraction containing autolytic activity. (b) Zymogram analysis of fractions 7-13 obtained from Mono Q chromatography ( $3 \mu \mathrm{g}$ total protein of each fraction). The position of a prestained low molecular mass marker (in $k D a$ ) is indicated on the left.

\section{Properties of the $38 \mathrm{kDa}$ autolysin}

Purity of the enzyme was demonstrated by SDS-PAGE, which showed a single band after staining with either Coomassie blue (Fig. 2, lane 4) or silver nitrate (data not shown). Furthermore, the enzyme preparation migrated as a single spot during 2-D gel electrophoresis (data not shown). The enzyme had an apparent molecular mass of $38 \mathrm{kDa}$ by comparison with calibrated SDS-PAGE standards (Fig. 2, lane 4). This compared closely with a molecular mass of $34 \mathrm{kDa}$ derived using Superdex 75 HR $10 / 30$ gel filtration. In addition, gel filtration indicated that the native $38 \mathrm{kDa}$ enzyme was a monomer.

Both prior to and after purification of the protein, several control experiments were performed to exclude the possibility that the clear zones observed on our zymograms were due to either protease activity or nonspecific displacement of dye during the staining process, as noted previously (Watt \& Clarke, 1994). After treatment with protease inhibitors, the activity of the $38 \mathrm{kDa}$ autolysin was not affected, whereas the activities of trypsin and chymotrypsin were totally inhibited. In addition, trypsin and chymotrypsin did not produce any clear zone in peptidoglycan-containing gels when run without inhibitors (data not shown). The second approach involved renaturing the gels over time. The clear zone in gels increased in intensity as time of renaturation increased from $5 \mathrm{~h}$ to maximum renaturation after $18 \mathrm{~h}$. 
Table 2. Amino acid composition of the M. phlei $38 \mathrm{kDa}$ autolysin

\begin{tabular}{|lcc|}
\hline $\begin{array}{l}\text { Amino } \\
\text { acid }\end{array}$ & $\begin{array}{r}\text { Amount } \\
\text { detected } \\
\text { (nmol) }\end{array}$ & $\begin{array}{c}\text { Residues } \\
\text { mol }^{-1} \dagger\end{array}$ \\
\hline Asp/Asn & 946 & 41 \\
Glu/Gln & 1080 & 47 \\
Ser & 500 & 22 \\
His & 152 & 7 \\
Arg & 513 & 22 \\
Thr & 392 & 17 \\
Ala & 975 & 42 \\
Pro & 496 & 22 \\
Tyr & 298 & 13 \\
Val & 1010 & 44 \\
Ile & 350 & 15 \\
Leu & 686 & 30 \\
Phe & 302 & 13 \\
Lys & 239 & 10 \\
\hline
\end{tabular}

* Cys, Met and Trp are not reported as they are oxidized during hydrolysis.

† Based on His $=7$ and a molecular mass of $38 \mathrm{kDa}$ for the autolysin.

This time dependence indicated that clearing in the gels was a characteristic of enzymic digestion of the mycobacterial cell walls. Boiling of samples in the absence of SDS-PAGE sample buffer for $4 \mathrm{~h}$ permanently denatured the $38 \mathrm{kDa}$ enzyme activity as monitored by the zymogram assay (which also indicated that the clear zone in gels was not due to other heat-stable non-specific interference).

The purified enzyme was tested using a spot assay in which buffers of various $\mathrm{pH}$ were incorporated into the agar to determine the activity $\mathrm{pH}$ optimum of the autolysin. After incubation for $24 \mathrm{~h}$, the activity of the enzyme on each plate was scored according to the size and transparency of the clearing zone formed. The $\mathrm{pH}$ optimum of the $38 \mathrm{kDa}$ autolysin was found to be $\mathrm{pH}$ 7.5 in both $20 \mathrm{mM}$ Tris $/ \mathrm{HCl}$ and $20 \mathrm{mM}$ sodium phosphate buffer. The activity of the enzyme was generally higher in Tris/ $\mathrm{HCl}$ buffer systems than in other buffers. Isoelectric focusing established the $\mathrm{pI}$ of this enzyme to be 5.5 by comparing it with the $\mathrm{pH}$ gradient formed in a gel or protein standards with known $\mathrm{pI}$. This estimation was derived from $\mathrm{pI}$ values of $5 \cdot 5-5 \cdot 7$ using the $\mathrm{pH}$-gradient method and $\mathrm{pI}$ values of $5 \cdot 3-5 \cdot 5$ using protein standards.

The amino acid composition of the $38 \mathrm{kDa}$ autolysin is shown in Table 2 . Of the total 345 residues calculated, $48 \%$ were hydrophobic. The protein contained only $12 \%$ basic residues (Arg, His and Lys), which is consistent with an enzyme of moderately acidic pI. Several attempts were made to sequence its $\mathrm{N}$-terminal residues by standard techniques but repeated failure suggested that the $\mathrm{N}$-terminus was blocked. However, we were able to obtain an internal amino acid sequence from an isolated tryptic peptide by nano-electrospray mass spectrometry (Wilm et al., 1996). The $1816 \mathrm{Da}$ peptide comprised the following sequence: $(\mathrm{V}, \mathrm{A})$ or (I/L,G)-V-K-A-T-T-T-E-E-E-T-E-(I/L)-P-A-K. The Nterminal residues in parentheses might be either $\mathrm{V}$-A or I/L-G with each pair in any order. Discrimination between $\mathrm{I}$ and $\mathrm{L}$ is not possible by this technique because both have the same mass.

A short sequence of 14 identified residues was not very useful for database searches; a search using the Atlas Retrieval System (ATLAS; National Biomedical Research Foundation, Washington, DC, USA) identified the V-K-A-T-T-T-E, T-T-T-E-E-E-T and E-E-E-T-E-L motifs in a variety of different proteins, none of which were related to peptidoglycan hydrolases. Likewise, and more importantly, a BLAST search of both the $M$. tuberculosis and $M$. leprae genome databases using this amino acid sequence failed to recover a hypothetical protein with predicted autolysin activity, but the P-A-K sequence was found in a hypothetical glycosyl hydrolase from $M$. tuberculosis with homology to $\alpha$-amylases.

Using $M$. smegmatis peptidoglycan as substrate in $20 \mathrm{mM}$ Tris/ $\mathrm{HCl}$ buffer, $\mathrm{pH} 7 \cdot 0$, containing $10 \mathrm{mM}$ $\mathrm{MgCl}_{2}$ and $0.1 \%(\mathrm{w} / \mathrm{v})$ Triton $\mathrm{X}-100$, the $38 \mathrm{kDa}$ autolysin $(2.06 \mu \mathrm{M})$ released $2.01 \pm 0.098 \mathrm{nmol}$ glucose equivalents per hour $(n=3)$ when reaction products were assayed for reducing sugars. This release of reducing sugars was directly proportional to the concentration of enzyme used in the assays (not shown). Free amino groups were not detected in parallel activity assays. These initial results suggest that the $38 \mathrm{kDa}$ autolysin is most probably a $\beta$-glycosidase and may be the first identification of an autolysin with glycolytic activity from the mycobacteria. It remains to be determined whether wall-associated polymers, such as mycolic acids and arabinogalactan, are important in the enzyme-substrate interaction. This is especially important since it is known that teichoic acid is involved in the binding of the amidase to the pneumococcal wall (Guidicelli \& Tomasz, 1984). As the peptidoglycanassociated substituents of mycobacterial walls account for a substantial proportion of the cell-wall mass, these polymers could also influence the activity of mycobacterial autolysins. Such enzyme-substrate interaction studies with the $38 \mathrm{kDa}$ autolysin will have to await the cloning and overexpression of its gene in view of both the restrictive quantities of enzyme produced by the cells and our failure to obtain sufficient quantities using the current protocol.

Our present studies have demonstrated that each of the five Mycobacterium species used in this study produced different sets of autolysins. M. phlei, for example, expressed two distinct autolysins, one of which has been purified to homogeneity. The general properties of this enzyme have been revealed and its primary target has been determined to be the glycan strands. Although a temporal study on the expression of the $38 \mathrm{kDa}$ autolysin during cell growth was not conducted, its activity in late-exponential growth would suggest that it plays 
an important role in cell-wall turnover, cell growth and division. Interestingly, the maximum autolytic activity was also detected during late-exponential growth in $M$. smegmatis (Kilburn \& Best, 1977), suggesting similar functions for the autolysins of this Mycobacterium species. Likewise, the major $26 \mathrm{kDa}$ autolysin of $P$. aeruginosa was demonstrated to be important in cell elongation and division, and possibly also in cell-wall turnover ( $\mathrm{Li}$ et al., 1996). Alternatively, the $38 \mathrm{kDa}$ autolysin could be expressed by dying cells of M. phlei.

The lytic action of this $38 \mathrm{kDa}$ glycosidase may also participate in the removal of immunologically important wall materials during cell-wall turnover in M. phlei, such as wax D. Intuitively, similar systems could operate in more medically important mycobacteria and contribute to pathogenesis. These complex lipooligosaccharides of peptidoglycan fragments covalently linked to arabinogalactan via a phosphodiester bond and in turn attached to mycolic acids have been obtained in vitro by treating cell walls of $M$. bovis BCG with bacteriolytic enzymes (Petit \& Lederer, 1984), and thought to occur naturally as an autolytic product (Goren \& Brennan, 1979). In animal hosts infected by pathogenic mycobacteria, this and related peptidoglycan turnover products would be highly immunogenic, mitogenic or arthrogenic. The consequences of these interactions with hosts would lead to inflammation or arthritis and may promote chronic debilitating diseases in the hosts (Barclay \& Wheeler, 1989; Petit \& Lederer, 1984). Clearly, the enzymes responsible for this important aspect of mycobacterial infection require further investigation.

\section{ACKNOWLEDGEMENTS}

We acknowledge the excellent technical assistance of Ken Payie, University of Guelph for FPLC, and we thank especially Ken Duncan of Glaxo Wellcome Research and Development for assisting in the nano-electrospray MS sequencing and for helpful advice. This work was supported by operating grants to T.J.B. and A. J. C. from the Canadian Bacterial Diseases Network, which is funded as a National Centre of Excellence.

\section{REFERENCES}

Barclay, R. \& Wheeler, P. R. (1989). Metabolism of mycobacteria in tissues. In The Biology of the Mycobacteria, vol 3, pp. 37-106. Edited by J. Stanford \& J. M. Grange. London: Academic Press.

Bernadsky, G., Beveridge, T. J. \& Clarke, A. J. (1994). Analysis of the sodium dodecyl sulfate-stable peptidoglycan autolysins of select gram-negative pathogens by using renaturing polyacrylamide gel electrophoresis. J Bacteriol 176, 5225-5232.

Clarke, A. J. \& Dupont, C. (1992). O-acetylated peptidoglycan: its occurrence, pathobiological significance, and biosynthesis. Can J Microbiol 38, 85-91.

Dolinger, D. L., Daneo-Moore, L. \& Shockman, G. D. (1989). The second peptidoglycan hydrolase of Streptococcus faecium ATCC 9790 covalently binds penicillin. J Bacteriol 171, 4355-4361.

Ellner, J. J. \& Daniel, T. M. (1979). Immunosuppression by mycobacterial arabinomannan. Clin Exp Immunol 35, 250-257.

Foster, S. J. (1992). Analysis of the autolysins of Bacillus subtilis 168 during vegetative growth and differentiation by using renaturing polyacrylamide gel electrophoresis. J Bacteriol 174, $464-470$.

Goodell, E. W. \& Schwartz, U. (1977). Enzymes synthesizing and hydrolyzing murein in Escherichia coli. Eur $J$ Biochem 81, 205-210.

Goren, M. B. \& Brennan, P. J. (1979). Mycobacterial lipids: chemistry and biologic activities. In Tuberculosis, pp. 69-193. Edited by G. P. Youmans. Philadelphia, PA: W. B. Saunders.

Ghuysen, J.-M., Tipper, D. J. \& Strominger, J. L. (1966). Enzymes that degrade bacterial cell walls. Methods Enzymol 8, 685-699.

Guidicelli, S. \& Tomasz, A. (1984). Attachment of pneumococcal autolysin to wall teichoic acids, an essential step in enzymatic wall degradation. J Bacteriol 158, 1188-1190.

Höltje, J.-V. (1996). Molecular interplay of murein synthases and murein hydrolases in Escherichia coli. Microb Drug Resist 2, 99-103.

Höltje, J.-V. (1998). Growth of the stress-bearing and shapemaintaining murein sacculus of Escherichia coli. Microbiol Mol Biol Rev 62, 181-203.

Hoyle, B. D. \& Beveridge, T. J. (1984). Metal binding by the peptidoglycan sacculus of Escherichia coli K-12. Can J Microbiol 30, 204-211.

Hunter, S. W., McNeil, M., Modlin, R. L., Mehra, V., Bloom, B. R. \& Brennan, P. J. (1989). Isolation and characterization of the highly immunological cell wall-associated protein of Mycobacterium leprae. J Immunol 142, 2864-2872.

Kilburn, J. O. \& Best, G. K. (1977). Characterization of autolysins from Mycobacterium smegmatis. J Bacteriol 29, 750-755.

Koch, A. L. (1990). Additional arguments for the key role of 'smart' autolysins in the enlargement of the wall of gramnegative bacteria. Res Microbiol 141, 529-541.

Lever, M. (1972). Carbohydrate determination with 4-hydroxybenzoic acid hydrazide (PAHBAH): effect of bismuth on the reaction. Anal Biochem 81, 21-27.

Li, Z. S., Dumas, F., Dubreuil, D. \& Jacques, M. (1993). A speciesspecific periplasmic flagella protein of Serpulina (Treponema) byodysenteriae. J Bacteriol 175, 8000-8007.

Li, Z. S., Clarke, A. J. \& Beveridge, T. J. (1996). A major autolysin of Pseudomonas aeruginosa: subcellular distribution, potential role in cell growth and division, and secretion in surface membrane vesicles. J Bacteriol 178, 2479-2488.

Moreno, C., Mehlert, A. \& Lamb, J. (1988). The inhibitory effects of mycobacterial lipoarabinomannan and polysaccharides upon polyclonal and monoclonal human $\mathrm{T}$ cell proliferation. Clin Exp Immunol 74, 206-210.

Paul, T. R. \& Beveridge, T. J. (1992). Re-evaluation of envelope profiles and cytoplasmic ultrastructure of mycobacteria processed by conventional embedding and freeze-substitution protocols. $J$ Bacteriol 174, 6508-6517.

Paul, T. R. \& Beveridge, T. J. (1994). Preservation of surface lipids and determination of ultrastructure of Mycobacterium kansasii by freeze-substitution. Infect Immun 62, 1542-1550.

Petit, J.-F. \& Lederer, E. (1984). The structure of the mycobacterial cell wall. In The Mycobacteria, part A, pp. 301-313. Edited by G. P. Kubica \& L. G. Wayne. New York: Marcel Dekker.

Puzo, G. (1990). The carbohydrate- and lipid-containing cell wall of mycobacteria, phenolic glycolipids: structure and immunological properties. Crit Rev Microbiol 17, 1101-1120.

Robertson, E. F., Dannelly, H. K., Malloy, P. J. \& Reeves, H. C. (1987). Rapid isoelectric focusing in a vertical polyacrylamide minigel system. Anal Biochem 167, 290-294. 
Rogers, H. J., Perkins, H. R. \& Ward, J. B. (1980). The bacterial autolysins. In Microbial Cell Walls and Membranes, pp. 437-460. Edited by H. J. Rogers, H. R. Perkins \& J. B. Ward. London: Chapman \& Hall.

Schleifer, K. H. \& Kandler, O. (1972). Peptidoglycan types of bacterial cell walls and their taxonomic implications. Bacteriol Rev 36, 407-471.

Schwartz, U., Asmus, A. \& Frank, H. (1969). Autolytic enzymes and cell division of Escherichia coli. J Mol Biol 41, 419-429.

Shockman, G. D. \& Höltje, J.-V. (1994). Microbial peptidoglycan (murein) hydrolases. In Bacterial Cell Wall, pp. 131-166. Edited by J.-M. Ghuysen \& R. Hakenbeck. Amsterdam: Elsevier.

Shockman, G. D., Daneo-Moore, L., Kariyama, R. \& Massidda, O. (1996). Bacterial walls, peptidoglycan hydrolases, autolysins and autolysis. Microb Drug Resist 2, 95-98.

Tomasz, A. (1984). Building and breaking of bonds in the cell wall of bacteria - the role for autolysin. In Microbial Cell Wall Synthesis and Autolysis, pp. 3-12. Edited by C. Nombela. Amsterdam : Elsevier.
Watt, S. R. \& Clarke, A. J. (1994). Initial characterization of two extracellular autolysins from Pseudomonas aeruginosa PAO1. J Bacteriol 176, 19-24.

Watt, S. R. \& Clarke, A. J. (1997). Isolation, purification and characterization of the major autolysin from Pseudomonas aeruginosa. Can J Microbiol 43, 1054-1062.

Wietzerbin, J., Das, B. C., Petit, J. F., Lederer, E., Leyh-Bouille, M. \& Ghuysen, J.-M. (1974). Occurrence of D-alanyl-D-mesodiaminopimelic acid and meso-diaminopimelyl-meso-diaminopimelic acid interpeptide linkages in mycobacteria. Biochemistry 13, 3471-3476.

Wilm, M., Shevchenko, A., Houthaeve, T., Breit, S., Schweigerer, L., Fotsis, T. \& Mann, M. (1996). Femtomole sequencing of proteins from polyacrylamide gels by nano-electrospray mass spectrometry. Nature 379, 466-469.

Received 20 April 1998; revised 24 August 1998; accepted 10 September 1998. 